\title{
Branched-chain Sugars. XXIII. Stereoselectivities in the Addition of Nucleophiles to Several 4-Uloses ${ }^{1)}$
}

\author{
Masafumi Matsuzawa, Ken-ichi Sato, Toshio Yasumori, and Juji Yoshimura* \\ Laboratory of Chemistry for Natural Products, Faculty of Science, Tokyo Institute of Technology, \\ Nagatsuta, Midori-ku, Yokohama 227 \\ (Received April 24, 1981)
}

\begin{abstract}
The stereoselectivities in the 1,2-addition of nucleophiles such as methylmagnesium iodide, vinylmagnesium bromide, and 2-lithio-2-methyl-1,3-dithiane to seven kinds of 4-uloses were examined. The configurations of $C$-vinyl derivatives obtained were determined from the chemical shifts of $\alpha$-carbons in ${ }^{13} \mathrm{C}$-NMR spectra.
\end{abstract}

In the preceding paper of this series ${ }^{1)}$ benzyl 2,3di- $O$-benzyl- $(\mathbf{1})$, and 2,3- $O$-methylene- $\beta$-L-threo-pentopyranosid-4-uloses (2), benzyl 2,3-di-O-benzyl-6-deoxy(3) and 6-deoxy-2,3- $O$-methylene- $\alpha$-D- $x y l o$-hexopyranosid-4-uloses (4), and methyl 6-deoxy-2,3-O-methylene$\alpha$-D-ribo-hexopyranosid-4-ulose (5) were synthesized as the starting materials for the synthesis of 2,3-O-methylene-4- $C$-substituted aldonolactones found in orthosomycins. ${ }^{2)}$ For this purpose, a two-carbon unit should be stereoselectively introduced into the carbonyl function of 2 and 4 . In this paper, stereoselectivities in the addition of nucleophiles to the above 4-uloses were examined, together with newly synthesized methyl 6 - deoxy - 2,3 - $O$ - methylene - $\alpha$ - D - lyxo-hexopyranosid-4ulose (6) and known methyl 2,3-di- $O$-benzyl-6-deoxy- $\alpha-$ D- $x$ ylo-hexopyranosid-4-ulose $(7){ }^{3)}$

\section{Results and Discussion}

The new 4-ulose 6 was synthesized as follows. Reaction of methyl 4,6- $O$-isopropylidene- $\alpha$-D-mannopyranoside $^{4)}$ in $N, N$-dimethylformamide with sodium hydride and dibromomethane gave the corresponding 2,3-O-methylene derivative (8) in $61 \%$ yield. Partial hydrolysis of 8 in $70 \%$ acetic acid at room temperature for $16 \mathrm{~h}$ gave the corresponding $O$-deisopropylidenated product $(\mathbf{9})$ in quantitative yield. Monotosylation of 9 gave the $6-O$-tosylate $(\mathbf{1 0})$ in $63 \%$ yield. Reduction of $\mathbf{1 0}$ in tetrahydrofuran with lithium aluminium hydride gave the 6-deoxy derivative (11) in $78 \%$ yield. Oxidation of $\mathbf{1 1}$ with dimethyl sulfoxide-trifluoroacetic anhydride $^{5)}$ gave 6 in $93 \%$ yield.

The coupling constants of $5\left(J_{1,2}=4.2, J_{2,3}=8.8\right.$, $\left.J_{3,5}=0.8 \mathrm{~Hz}\right)$ and $6\left(J_{1,2}=0, J_{2,3}=6.4 \mathrm{~Hz}\right)$ indicate that these compounds exist in a boat or a skew-boat conformation, but not in the usual $C 1$ conformation. Collins and Whitton ${ }^{6}$ ) suggested the ${ }^{\circ} \mathrm{S}_{4}$ conformation to the 2,3-O-isopropylidene analogue $\left(J_{1,2}=3.8, J_{2,3}=\right.$ $9.0, J_{3,5}=1.2 \mathrm{~Hz}$ ) of 5 , however, the assingment of ${ }^{1.4} \mathrm{~B}$ for 5 and the ${ }^{\circ} \mathrm{S}_{4}$ for 6 will be more probable from $J_{2,3}$ values.

As the nucleophiles for 1,2-addition to 4-uloses, methylmagnesium iodide, methyllithium, vinylmagnesium bromide, and 2-lithio-2-methyl-1,3-dithiane were used, and the results were summarized in Table 1.

The configuration of products in these reactions was mainly determined from the chemical shifts of the branching $\alpha$-carbons in ${ }^{13} \mathrm{G}$ NMR spectra. Application of the fact that equatorially oriented $C$-methyl carbons are deshielded with respect to axially oriented methyl carbons for the configurational assignment of

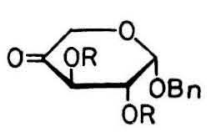

(1) $\mathrm{R}=\mathrm{Bn}$

(2) $\mathrm{R}, \mathrm{R}=\mathrm{CH}_{2}$

$B n=b e n z y l$

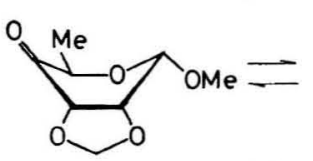

$1,4 \mathrm{~B}$

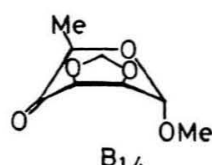

$\mathrm{B}_{1,4}$

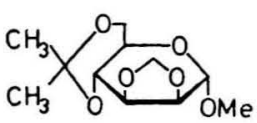

(8)

(5)

(6)

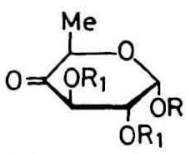

(3) $R=R_{1}=B n$

(4) $\mathrm{R}=\mathrm{Bn}, \mathrm{R}_{1}, \mathrm{R}_{1}=\mathrm{CH}_{2}$

(7) $\mathrm{R}=\mathrm{Me}, \mathrm{R}_{1}=\mathrm{Bn}$

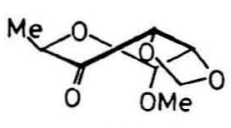

${ }^{0} S_{4}$
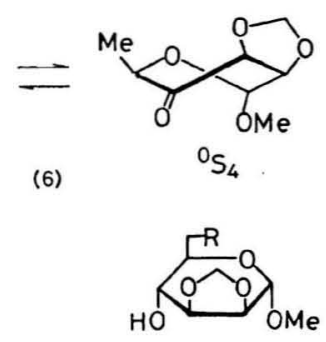

(9) $\mathrm{R}=\mathrm{OH}$

(10) $R=O T s$

(11) $R=H$
$C$-methylhexopyranosides? ${ }^{7}$ has been extended to the 1,3-dithian-2-yl, ${ }^{8}$, hydroxymethyl, ${ }^{9}{ }^{9}$ nitromethyl, ${ }^{10)}$ and benzoylaminomethy ${ }^{10)}$ derivatives. As shown in Table 2 , this principle was successfully used for the determination of the configuration of 4- $C$-vinyl derivatives, by the comparison of the chemical shifts of methin carbons in the vinyl groups. However, this trend could not be observed in those of methylene carbons in vinyl groups. Miljkovic et al. depicted that there are $c a .6 \mathrm{ppm}$ difference in the chemical shifts between axial and equatorial $C$-methyl carbons. ${ }^{7}$ The smaller differences between 12 and 13 , and 14 and 15 indicate that the conformation of pentopyranosides having an axial substituent tends to deviate from $C l$.

The configurations of epimeric 4-C-(2-methyl-1,3dithian-2-yl) derivatives (16 and 17) were determined from the fact that 16 exists in $1 C\left(J_{1,2}=1.3, J_{2,3}=\right.$ $3.0 \mathrm{~Hz})$, whereas 17 in $C 1\left(J_{1,2}=4.0, J_{2,3}=9.2 \mathrm{~Hz}\right)$ conformation. It is known that this bulky group in axial orientation causes a similar inversion of the conformation to that of 16. ${ }^{11)}$ The reliability of these assignments was proved by the actual derivation of 15, 22, and 28 into naturally occuring branchedchain sugars ${ }^{12,13)}$ and also by the establishment of a principle for the determination of the chirality of 
TABle 1. Nugleophilic Reactions of 4-Uloses

\begin{tabular}{|c|c|c|c|c|c|c|c|c|}
\hline \multirow{2}{*}{ Run } & \multirow{2}{*}{ 4-Ulose } & \multirow{2}{*}{ Nucleophile } & \multicolumn{2}{|c|}{ Conditions } & \multicolumn{3}{|c|}{ Ratio of products } & \multirow{2}{*}{ Yield $/ \%$} \\
\hline & & & Solvent & Temp & Axial & equatorial & attack & \\
\hline $\begin{array}{l}1 \\
2 \\
3 \\
4 \\
5\end{array}$ & 1 & $\begin{array}{l}\text { MeMgI } \\
\text { MeMgI } \\
\text { MeLi } \\
\mathrm{CH}_{2}=\mathrm{CHMgBr} \mathrm{Mg} \\
\mathrm{DTNLi}^{\mathrm{a}}\end{array}$ & $\begin{array}{l}\text { Ether } \\
\text { Ether-THF } \\
\text { Ether } \\
\text { THF } \\
\text { THF }\end{array}$ & $\begin{array}{l}-78^{\circ} \mathrm{C} \\
\mathrm{RT}^{\circ} \\
\mathrm{RT} \\
\mathrm{RT} \\
-30^{\circ} \mathrm{C}\end{array}$ & $\begin{array}{l}(\mathbf{1 2}) \\
(\mathbf{1 2}) \\
(\mathbf{1 2}) \\
(\mathbf{1 4}) \\
(\mathbf{1 6})\end{array}$ & $\begin{aligned} 1 & : 2.6 \\
2.5 & : 1 \\
1 & : 0 \\
2.5 & : 1 \\
2.5 & : 1\end{aligned}$ & $\begin{array}{l}(\mathbf{1 3}) \\
(\mathbf{1 3}) \\
(\mathbf{1 5}) \\
(\mathbf{1 7})\end{array}$ & $\begin{array}{l}98 \\
84.5 \\
32 \\
48 \\
35\end{array}$ \\
\hline $\begin{array}{l}6 \\
7\end{array}$ & 2 & $\begin{array}{l}\mathrm{MeMgI} \\
\mathrm{CH}_{2}=\mathrm{CHMgBr}\end{array}$ & $\begin{array}{l}\text { Ether-THF } \\
\text { THF }\end{array}$ & $\begin{array}{l}\text { RT } \\
\text { RT }\end{array}$ & $\begin{array}{l}(\mathbf{1 8}) \\
(\mathbf{2 0})\end{array}$ & $\begin{array}{l}1: 2.8 \\
1: 4.6\end{array}$ & $\begin{array}{l}(19) \\
(21)\end{array}$ & $\begin{array}{l}72 \\
59\end{array}$ \\
\hline 8 & 3 & $\mathrm{CH}_{2}=\mathrm{CHMgBr}$ & THF & RT & & $0: 1$ & (22) & 44 \\
\hline $\begin{array}{r}9 \\
10 \\
11 \\
12\end{array}$ & $\begin{array}{l}7 \\
4\end{array}$ & $\begin{array}{l}\mathrm{MeMgI} \\
\mathrm{MeMgI} \\
\mathrm{CH}_{2}=\mathrm{CHMgBr} \\
\mathrm{DTNLi}^{\mathrm{a})}\end{array}$ & $\begin{array}{l}\text { Ether } \\
\text { Ether-THF } \\
\text { THF } \\
\text { THF }\end{array}$ & $\begin{array}{l}\text { RT } \\
\text { RT } \\
\text { RT } \\
\text { RT }\end{array}$ & $\begin{array}{l}(23) \\
(26)\end{array}$ & $\begin{array}{ll}1 & : 2.2 \\
0 & : 1 \\
1 & : 15 \\
0 & : 1\end{array}$ & $\begin{array}{l}(24) \\
(25) \\
(27) \\
(28)\end{array}$ & $\begin{array}{l}86 \\
89 \\
55 \\
35\end{array}$ \\
\hline 13 & 5 & MeMgI & Ether-THF & $\mathrm{RT}$ & (29) & $1: 0$ & & 95 \\
\hline 14 & 6 & MeMgI & Ether & RT & & $0: 1$ & (30) & 96 \\
\hline
\end{tabular}

a) The abbreviation of 2-lithio-2-methyl-1,3-dithiane.

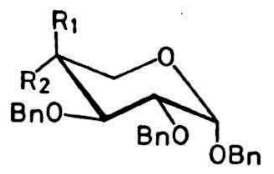

(12) $R_{1}=M e, R_{2}=O H$ (13) $\mathrm{R}_{1}=\mathrm{OH}, \mathrm{R}_{2}=\mathrm{Me}$ (14) $\mathrm{R}_{1}=-\mathrm{CH}=\mathrm{CH}_{2}, \mathrm{R}_{2}=\mathrm{OH}$ (15) $\mathrm{R}_{1}=\mathrm{OH}, \mathrm{R}_{2}=-\mathrm{CH}=\mathrm{CH}_{2}$ (16) $R_{1}=D T N, R_{2}=O H$ (17) $\mathrm{R}_{1}=\mathrm{OH}, \mathrm{R}_{2}=\mathrm{OTN}$

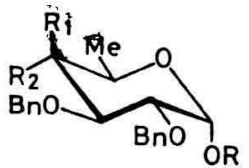

(2) $\mathrm{R}=\mathrm{Bn}, \mathrm{R}_{1}=\mathrm{OH}, \mathrm{R}_{2}=\mathrm{CH}=\mathrm{CH}_{2}$ (23) $R=M e, R_{1}=M e, R_{2}=O H$
(24) $R=M e, R_{1}=O H, R_{2}=M e$

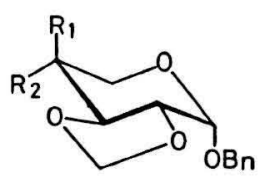

(18) $\mathrm{R}_{1}=\mathrm{Me}, \mathrm{R}_{2}=\mathrm{OH}$ (19) $\mathrm{R}_{1}=\mathrm{OH}, \mathrm{R}_{2}=\mathrm{Me}$ (20) $\mathrm{R}_{1}=-\mathrm{CH}=\mathrm{CH}_{2}, \mathrm{R}_{2}=\mathrm{OH}$ (21) $\mathrm{R}_{1}=\mathrm{OH}, \mathrm{R}_{2}=\mathrm{CH}=\mathrm{CH}_{2}$

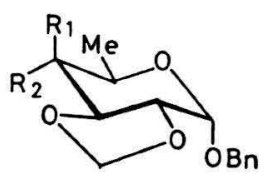

(25) $R_{1}=O H, R_{2}=M e$

(26) $\mathrm{R}_{1}=\mathrm{CH}=\mathrm{CH}_{2}, \mathrm{R}_{2}=\mathrm{OH}$

(27) $\mathrm{R}_{1}=\mathrm{OH}, \mathrm{R}_{2}=\mathrm{CH}=\mathrm{CH}_{2}$ (28) $R_{1}=O H, R_{2}=D T N$
Table 2. Determination of the configurations of 4-EPIMERS FROM THE CHEMICAL SHIFTS OF BRANCHING $\alpha$-CARBONS IN ${ }^{13}$ C-NMR SPECTRA

\begin{tabular}{|c|c|c|c|}
\hline \multicolumn{4}{|c|}{$\begin{array}{l}\text { Chemical shifts (ppm) of } \alpha \text {-carbons of } \\
\text { 4-C-substituted epimers }\end{array}$} \\
\hline \multicolumn{2}{|c|}{$C$-Methyl derivatives } & \multicolumn{2}{|c|}{$C$-Vinyl derivatives } \\
\hline Axial & Equatorial & Axial & Equatorial \\
\hline $20.4(12)$ & $22.8(13)$ & $137.1(14)$ & $138.5(15)$ \\
\hline $15.8(18)$ & $22.0(19)$ & $135.2(20)$ & $137.2(21)$ \\
\hline \multirow[t]{2}{*}{$14.9(23)$} & $22.3(24)$ & & $139.7(22)$ \\
\hline & $22.1(25)$ & $132.7(\mathbf{2 6})$ & $137.6(27)$ \\
\hline $18.4(29)$ & $21.1(30)$ & & \\
\hline
\end{tabular}

1-hydroxyethyl groups introduced via the corresponding vinyl and ethylidene derivatives. ${ }^{14}$ )

In the results of 1 (Runs $1-5$ ) shown in Table 1 , it is characteristic that the axial attack generally predominates over the equatorial attack, excepting the Grignard reaction in ether at $-78{ }^{\circ} \mathrm{G}$. The complementary stereoselectivity between the Grignard and methyllithium reactions at lower temperature was also observed in the cases of methyl 2,3-di- $O$-methyland 2,3-di- $O$-mesyl-6- $O$-trityl- $\alpha$-D- $x y l o$-hexopyranosid-4uloses. ${ }^{7}$ The reason for this remarkable fact should be pursued in more detail. The predominancy of the axial attack will be attributed again to changeable conformation of $\mathbf{1}$, because the equatorial attacks are predominant in the case of 2 (Runs 6, 7) in which the 2,3-O-methylene ring prohibits the inversion of the $C 1$ conformation. A similar trend is also observed in the reaction of 7 and 4 (Runs 9, 10) with methylmagnesium iodide, though the equatorial attack is predominant in these hexopyranosides. In the cases of 5 and 6, the nucleophile exclusively approaches to the carbonyl function from the opposite side of the bulky 2,3-O-methylene ring. Similar stereoselec- 
TABle 3. 'H NMR PARAmeters OF 4- $C$-METHYL DeRivatives

\begin{tabular}{|c|c|c|c|c|c|c|c|}
\hline \multicolumn{8}{|c|}{ Chemical shifts $(\delta)$ and coupling constants $(\mathrm{Hz})$} \\
\hline $\begin{array}{l}\text { 4- } C \text {-Methyl } \\
\text { derivative }\end{array}$ & $\begin{array}{c}\mathrm{H}-1 \\
\left(J_{1,2}\right)\end{array}$ & $\begin{array}{l}\mathrm{H}-2 \\
\left(J_{2,3}\right)\end{array}$ & $\mathrm{H}-3$ & $\begin{array}{l}\mathrm{H}-5 \mathrm{e} \\
\left(J_{5 \mathrm{e}, 5 \mathrm{a}}\right)\end{array}$ & $\begin{array}{l}\mathrm{H}-5 \mathrm{a} \\
\left(J_{5,6}\right)\end{array}$ & H-6 & Other protons \\
\hline 12 & $\begin{array}{l}4.76 \mathrm{~d} \\
(2.8)\end{array}$ & $\begin{array}{l}3.49 \mathrm{dd} \\
(7.2)\end{array}$ & $3.66 \mathrm{~d}$ & $\begin{array}{l}3.66 \mathrm{~d} \\
(11.5)\end{array}$ & $3.41 \mathrm{~d}$ & & $\begin{array}{l}7.4-7.1(\mathrm{Ph} ; \mathrm{m}), 4.4-5.1\left(\mathrm{CH}_{2} \mathrm{Ph} ; \mathrm{m}\right), \\
2.50(\mathrm{OH}), 1.20(\mathrm{CMe})\end{array}$ \\
\hline 13 & $\begin{array}{l}4.90 \mathrm{~d} \\
(3.1)\end{array}$ & $\begin{array}{l}3.85 \mathrm{dd} \\
(9.6)\end{array}$ & $3.68 \mathrm{~d}$ & $\begin{array}{l}3.64 \mathrm{~d} \\
(12.0)\end{array}$ & $3.45 \mathrm{~d}$ & & $\begin{array}{l}7.5-7.0(\mathrm{Ph} ; \mathrm{m}), 4.4-5.1\left(\mathrm{CH}_{2} \mathrm{Ph} ; \mathrm{m}\right), \\
2.35(\mathrm{OH}), 1.14(\mathrm{CMe})\end{array}$ \\
\hline 18 & $\begin{array}{l}5.26 \mathrm{~d} \\
(3.8)\end{array}$ & $\begin{array}{l}3.32 \mathrm{dd} \\
(9.8)\end{array}$ & $3.90 \mathrm{~d}$ & $\begin{array}{l}3.50 \mathrm{~d} \\
(11.3)\end{array}$ & $3.34 \mathrm{~d}$ & & $\begin{array}{l}7.4-7.2(\mathrm{Ph} ; \mathrm{m}), 5.13 \text { and } 5.10 \\
\left(\mathrm{OCH} \mathrm{O}_{2} \text {; each s }\right), 4.8-4.5\left(\mathrm{CH}_{2} \mathrm{Ph} ; \mathrm{m}\right) \text {, } \\
2.16(\mathrm{OH}), 1.39(\mathrm{CMe})\end{array}$ \\
\hline 19 & $\begin{array}{l}5.35 \mathrm{~d} \\
(3.1)\end{array}$ & $\begin{array}{l}3.84 \mathrm{dd} \\
(10.0)\end{array}$ & $3.72 \mathrm{~d}$ & & & & $\begin{array}{l}7.5-7.3(\mathrm{Ph} ; \mathrm{m}), 5.14 \text { and } 5.08 \\
\left(\mathrm{OCH}_{2} \mathrm{O} ; \mathrm{ABq}, J=1.0\right), 4.7-4.4 \\
\left(\mathrm{CH}_{2} \mathrm{Ph} ; \mathrm{m}\right), 2.40(\mathrm{OH}), 1.39(\mathrm{CMe})\end{array}$ \\
\hline 23 & $\begin{array}{l}4.55 \mathrm{~d} \\
(3.8)\end{array}$ & $\begin{array}{l}3.44 \mathrm{dd} \\
(9.8)\end{array}$ & $3.74 \mathrm{~d}$ & & $\begin{array}{l}3.74 \mathrm{q} \\
(6.0)\end{array}$ & $1.11 \mathrm{~d}$ & $\begin{array}{l}7.4-7.2(\mathrm{Ph} ; \mathrm{m}), 4.4-5.1\left(2 \times \mathrm{CH}_{2} \mathrm{Ph}\right. \\
2 \times \mathrm{ABq}, J=11.5,11.8), 3.36(\mathrm{OMe}) \\
1.99(\mathrm{OH}), 1.13(\mathrm{CMe})\end{array}$ \\
\hline 24 & $\begin{array}{l}4.60 \mathrm{~d} \\
(3.8)\end{array}$ & $\begin{array}{l}3.86 \mathrm{dd} \\
(9.5)\end{array}$ & $3.58 \mathrm{~d}$ & & $\begin{array}{l}3.71 \mathrm{q} \\
(6.5)\end{array}$ & $1.21 \mathrm{~d}$ & $\begin{array}{l}7.4-7.2(\mathrm{Ph} ; \mathrm{m}), 4.5-5.0\left(2 \times \mathrm{CH}_{2} \mathrm{Ph}\right. \\
2 \times \mathrm{ABq}, J=11.5,10.8), 3.38(\mathrm{OMe}) \\
2.27(\mathrm{OH}), 1.12(\mathrm{CMe})\end{array}$ \\
\hline 25 & $\begin{array}{l}5.30 \mathrm{~d} \\
(3.2)\end{array}$ & $\begin{array}{l}3.78 \mathrm{dd} \\
(10.5)\end{array}$ & $3.77 \mathrm{~d}$ & & $\begin{array}{l}3.58 \mathrm{q} \\
(6.4)\end{array}$ & $1.18 \mathrm{~d}$ & $\begin{array}{l}7.5-7.2(\mathrm{Ph} ; \mathrm{m}), 5.10 \text { and } 5.15 \\
\left(\mathrm{OCH}_{2} \mathrm{O} ; \mathrm{ABq}, J=1.0\right), 4.72 \text { and } 4.68 \\
\left(\mathrm{CH}_{2} \mathrm{Ph} ; \mathrm{ABq}, J=12.0\right), 2.25(\mathrm{OH}), \\
1.31(\mathrm{CMe})\end{array}$ \\
\hline 29 & $\begin{array}{l}4.68 \mathrm{~d} \\
(5.2)\end{array}$ & $\begin{array}{l}4.21 \mathrm{t} \\
(5.6)\end{array}$ & $3.86 \mathrm{~d}$ & & $\begin{array}{l}3.93 \mathrm{q} \\
(6.7)\end{array}$ & $1.22 \mathrm{~d}$ & $\begin{array}{l}5.25 \text { and } 5.02\left(\mathrm{OCH}_{2} \mathrm{O} ; \mathrm{ABq}, J=2.0\right) \text {, } \\
3.38(\mathrm{OMe}), 2.35(\mathrm{OH}), 1.21(\mathrm{CMe})\end{array}$ \\
\hline 30 & $\begin{array}{l}5.00 \mathrm{~d} \\
(0.5)\end{array}$ & $\begin{array}{l}3.88 \mathrm{dd} \\
(5.3)\end{array}$ & $3.76 \mathrm{~d}$ & & $\begin{array}{l}3.70 \mathrm{q} \\
(6.6)\end{array}$ & $1.23 \mathrm{~d}$ & $\begin{array}{l}5.31 \text { and } 4.91\left(\mathrm{OCH}_{2} \mathrm{O} ; \mathrm{ABq}, J=1.4\right) \text {, } \\
3.43(\mathrm{OMe}), 2.40(\mathrm{OH}), 1.14(\mathrm{CMe})\end{array}$ \\
\hline
\end{tabular}

Table 4. ${ }^{1} \mathrm{H}$ NMR Parameters of 4-C-vinyl Derivatives

\begin{tabular}{|c|c|c|c|c|c|c|c|c|c|}
\hline \multirow[b]{2}{*}{$4-C$-Vinyl } & \multicolumn{8}{|c|}{ Chemical shifts $(\delta)$ and coupling constants $(\mathrm{Hz})^{\text {a) }}$} & \multirow[b]{2}{*}{$\begin{array}{l}\mathrm{OCH}_{2} \mathrm{O} \\
\left(J_{\mathrm{ABq}}\right)\end{array}$} \\
\hline & $\begin{array}{l}\mathrm{H}-1 \\
\left(J_{1,2}\right)\end{array}$ & $\begin{array}{c}\mathbf{H}-2 \\
\left(J_{2,3}\right)\end{array}$ & H-3 & $\begin{array}{c}\mathrm{H}-5 \mathrm{e} \\
\left(J_{5 \mathrm{e} .5 \mathrm{a}}\right)\end{array}$ & $\begin{array}{l}\mathrm{H}-5 \mathrm{a} \\
\left(J_{5,6}\right)\end{array}$ & H-6 & $\begin{array}{l}\mathrm{H}-4 \alpha \text { and } \mathrm{H}-4 \beta \\
\left(J_{\text {trans, cis, gem }}\right)\end{array}$ & $\mathrm{OH}$ & \\
\hline 14 & $\begin{array}{l}4.51 \mathrm{~d} \\
(3.0)\end{array}$ & $\begin{array}{l}3.83 \mathrm{dd} \\
(10.0)\end{array}$ & $3.92 \mathrm{~d}$ & $\begin{array}{l}3.72 \mathrm{dd} \\
(11.5)\end{array}$ & $3.35 \mathrm{~d}$ & & $\begin{array}{c}5.80 \mathrm{dd}, 5.50 \mathrm{dd}, 5.27 \mathrm{dd} \\
(16.2,9.8,2.1)\end{array}$ & $2.71 \mathrm{~d}^{b)}$ & \\
\hline 15 & $\begin{array}{l}4.82 \mathrm{~d} \\
(2.9)\end{array}$ & $\begin{array}{l}3.56 \mathrm{dd} \\
(9.1)\end{array}$ & $3.74 \mathrm{~d}$ & $\begin{array}{l}3.74 \mathrm{~d} \\
(11.5)\end{array}$ & $3.63 \mathrm{~d}$ & & $\begin{array}{c}6.09 \mathrm{dd}, 5.49 \mathrm{dd}, 5.26 \mathrm{dd} \\
(16.7,10.0,2.0)\end{array}$ & 3.22 & \\
\hline 20 & $\begin{array}{l}5.26 \mathbf{d} \\
(3.3)\end{array}$ & $\begin{array}{l}3.37 \mathrm{dd} \\
(9.2)\end{array}$ & $4.01 \mathrm{~d}$ & $\begin{array}{l}3.62 \mathrm{~d} \\
(10.8)\end{array}$ & $3.56 \mathrm{~d}$ & & $\begin{array}{c}6.12 \mathrm{dd}, 5.52 \mathrm{dd}, 5.32 \mathrm{dd} \\
(17.6,11.0,1.8)\end{array}$ & 2.96 & $\begin{array}{l}5.09 \mathrm{~d}, 5.03 \mathrm{~d} \\
(1.0)\end{array}$ \\
\hline 21 & $\begin{array}{l}5.38 \mathrm{~d} \\
(3.0)\end{array}$ & $\begin{array}{l}3.90 \mathrm{dd} \\
(9.4)\end{array}$ & $3.97 \mathrm{~d}$ & $\begin{array}{l}3.54 \mathrm{~d} \\
(11.0)\end{array}$ & $3.47 \mathrm{~d}$ & & $\begin{array}{c}5.86 \mathrm{dd}, 5.53 \mathrm{dd}, 5.30 \mathrm{dd} \\
(16.7,10.0,2.0)\end{array}$ & 3.05 & $\begin{array}{l}5.15 \mathrm{~d}, 5.07 \mathrm{~d} \\
(1.0)\end{array}$ \\
\hline 22 & $\begin{array}{l}4.83 \mathrm{~d} \\
(3.0)\end{array}$ & $\begin{array}{l}3.80 \mathrm{dd} \\
(9.8)\end{array}$ & $3.88 \mathrm{~d}$ & & $\begin{array}{l}3.93 \mathrm{q} \\
(6.5)\end{array}$ & $1.11 \mathrm{~d}$ & $\begin{array}{c}5.77 \mathrm{dd}, 5.41 \mathrm{dd}, 5.28 \mathrm{dd} \\
(17.0,10.0,2.0)\end{array}$ & 2.54 & \\
\hline 26 & $\begin{array}{l}5.28 \mathrm{~d} \\
(3.5)\end{array}$ & $\begin{array}{l}3.52 \mathrm{dd} \\
(10.0)\end{array}$ & $4.03 \mathrm{~d}$ & & $\begin{array}{l}3.75 \mathrm{q} \\
(6.5)\end{array}$ & $1.05 \mathrm{~d}$ & $\begin{array}{c}5.99 \mathrm{dd}, 5.55 \mathrm{dd}, 5.46 \mathrm{dd} \\
(17.6,11.0,2.0)\end{array}$ & 2.47 & $\begin{array}{l}5.12 \mathrm{~d}, 5.07 \mathrm{~d} \\
(1.0)\end{array}$ \\
\hline 27 & $\begin{array}{l}5.35 \mathrm{~d} \\
(3.0)\end{array}$ & $\begin{array}{l}3.88 \mathrm{dd} \\
(9.5)\end{array}$ & $4.01 \mathrm{~d}$ & & $\begin{array}{l}3.72 \mathrm{q} \\
(7.0)\end{array}$ & $1.12 \mathrm{~d}$ & $\begin{array}{c}5.84 \mathrm{dd}, 5.48 \mathrm{dd}, 5.32 \mathrm{dd} \\
(17.0,10.4,1.9)\end{array}$ & 2.14 & $\begin{array}{l}5.18 \mathrm{~d}, 5.10 \mathrm{~d} \\
(1.0)\end{array}$ \\
\hline
\end{tabular}

a) Data of protons in benzyl groups were omitted. b) $J_{\mathrm{OH}, 5 \mathrm{e}}=3.0$ was observed.

tivities were also observed in the reduction of $2,3-O$ isopropylidene analogue of $5^{6}$ ) and 2,3-O-isopropylidene analogue of $6^{15}$ ) and the Grignard reaction ${ }^{16)}$ of the enantiomer of the latter. It is obvious that bulkier nucleophiles such as vinylmagnesium bromide and 2lithio-2-methyl-1,3-dithiane (Runs 7, 8, 11, 12) afford selectively the equatorial attack products, unless otherwise a special steric hindrance is present.

${ }^{1} \mathrm{H}$ NMR parameters of $4-C$-methyl and 4- $C$-vinyl derivatives thus obtained were shown in Tables 3 and 4 , respectively. Among $C$-methyl derivatives, coupling constants $\left(J_{1,2}\right.$ and $\left.J_{2,3}\right)$ of 29 and 30 indicate that these compounds exist in the usual allo and talo configurations, respectively. The parameters shown in the both tables will be reasonable for the individual compounds.

\section{Experimental}

General Methods. Melting points were determined with a Mel-Temp melting point apparatus and not corrected. Optical rotations were measured at room tem- 
perature in $0.5 \mathrm{dm}$ tube with Carl Zeiss LEP-Al or JASCO DIP-4 polarimeter, using chloroform as a solvent. ${ }^{1} \mathrm{H}$ NMR spectra were recorded with a JEOL JNM PS-100 spectrometer in deuteriochloroform containing tetramethylsilane as the internal reference. ${ }^{13} \mathrm{G}-\mathrm{NMR}$ data (Table 2) were obtained at $30^{\circ} \mathrm{C}$ on a JEOL JNM FX-100 spectrometer in the pulse Fourier transform/proton noise decoupled mode at $25.15 \mathrm{MHz}$ in deuteriochloroform. Each spectrum was obtained after 1000 transients with a frequency range of $5000 \mathrm{~Hz}$. The pulse angle of $45^{\circ}$ was used, with an acquisition time of $0.8 \mathrm{~s}$ and a pulse delay of $0.7 \mathrm{~s}$. Chemical shifts and coupling constants were recorded in $\delta$ (ppm) and $\mathrm{Hz}$ units. Evaporations were conducted under diminished pressure.

Methyl 4,6-O-Isopropylidene-2,3-O-methylene- $\alpha$-D-mannopyranoside (8). To a solution of methyl 4,6- $O$-isopropyridene$\alpha$-D-mannopyranoside $(5.0 \mathrm{~g}, 21.3 \mathrm{mmol})$ and sodium hydride $(1.5 \mathrm{~g}, 65 \mathrm{mmol})$ in $N, N$-dimethylformamide $(10 \mathrm{ml}$, DMF) was added dibromomethane $(11.5 \mathrm{~g}, 65 \mathrm{mmol})$ at $0{ }^{\circ} \mathrm{C}$. After keeping the mixture at $0-5{ }^{\circ} \mathrm{C}$ for $2 \mathrm{~h}$, the solution was poured into cold water, and extracted with ether. The extract was washed with water, dried, and evaporated to give a syrup which was purified on a silicagel column (benzene-ethyl acetate $5: 1$ ) to give a colorless syrup $8(3.2 \mathrm{~g}, 60.9 \%) .[\alpha]_{\mathrm{D}}+2.0^{\circ}$ (c 1.9); NMR: 5.19 and 4.94. (each s, $\left.2 \mathrm{H}, \mathrm{OCH}_{2} \mathrm{O}\right), 4.97(\mathrm{~s}, 1 \mathrm{H}, \mathrm{H}-1), 4.25-$ $3.50\left(\mathrm{~m}, 6 \mathrm{H}, \mathrm{H}-2,3,4,5,6,6^{\prime}\right), 3.38$ (s, $\left.3 \mathrm{H}, \mathrm{OMe}\right), 1.50$ and 1.42 (each s, $6 \mathrm{H}, 2 \times \mathrm{CMe}$ ). Found: $\mathrm{C}, 53.54 ; \mathrm{H}, 7.52 \%$. Calcd for $\mathrm{C}_{11} \mathrm{H}_{18} \mathrm{O}_{6}: \mathrm{C}, 53.65 ; \mathrm{H}, 7.37 \%$.

Methyl 2,3-O-Methylene- $\alpha-\mathrm{D}-$ mannopyranoside (9). Partial hydrolysis of $8(2.0 \mathrm{~g}, 8.1 \mathrm{mmol})$ in $70 \%$ acetic acid $(20 \mathrm{ml})$ under reflux for $2 \mathrm{~h}$ gave the corresponding $O$ deisopropylidenated product 9 in quantitative yield (1.67 g). $\mathrm{Mp} 74-75^{\circ} \mathrm{C}$ (ethyl acetate), $[\alpha]_{\mathrm{D}}+29.6^{\circ}$ (c 1.1 ); NMR: 5.17 and 4.98 (each s, $2 \mathrm{H}, \mathrm{OCH}_{2} \mathrm{O}$ ), 4.96 (s, 1H, $\mathrm{H}-1$ ), 4.21 (dd, $1 \mathrm{H}, J_{2,3}=5.8, J_{3,4}=7.0, \mathrm{H}-3$ ), 3.89 (d, $1 \mathrm{H}$, $\mathrm{H}-2), 3.85$ (d, 2H, $J_{5,6}=3.4, \mathrm{H}-6$ and $\left.\mathrm{H}-6^{\prime}\right), 3.80-3.55$ $(\mathrm{m}, 2 \mathrm{H}, \mathrm{H}-4$ and $\mathrm{H}-5), 3.40$ (s, 3H, OMe). Found: $\mathrm{C}$, $46.75 ; \mathrm{H}, 6.90 \%$. Calcd for $\mathrm{C}_{8} \mathrm{H}_{14} \mathrm{O}_{6}: \mathrm{C}, 46.60 ; \mathrm{H}, 6.84 \%$.

Methyl 2,3-O-Methylene-6-O-p-tolylsulfonyl- $\alpha$-D-mannopyranoside (10). To a solution of $9(1.0 \mathrm{~g}, 4.85 \mathrm{mmol})$ in pyridine $(10 \mathrm{ml})$ was added $p$-toluenesulfonyl chloride (1.4 g, $7.4 \mathrm{mmol})$ in dry benzene $(15 \mathrm{ml})$ at $0{ }^{\circ} \mathrm{C}$ with stirring. After standing at $0^{\circ} \mathrm{C}$ for $16 \mathrm{~h}$, the solution was poured into ice-water and extracted with chloroform. The extract was processed as usual to give a syrup. The syrup was purified on a silica-gel column (benzene-acetone $8: 1$ ) to give a colorless $10(1.1 \mathrm{~g}, 62.9 \%)$. $[\alpha]_{\mathrm{D}}+6.5^{\circ}(c 1.2)$; NMR: 7.78 and 7.30 (each d, $4 \mathrm{H}, J=8.0, \mathrm{Ph}$ ), 5.13 and 4.95 (each s, $\left.2 \mathrm{H}, \mathrm{OCH}_{2} \mathrm{O}\right), 4.88(\mathrm{~s}, 1 \mathrm{H}, \mathrm{H}-1), 4.27\left(\mathrm{~d}, 2 \mathrm{H}, J_{5,6}=3.6\right.$, H-6 and H-6'), 4.16 (q, $1 \mathrm{H}, J_{2,3}=5.8, J_{3,4}=7.0, \mathrm{H}-3$ ), $3.86(\mathrm{~d}, 1 \mathrm{H}, \mathrm{H}-2), 3.40-3.76(\mathrm{~m}, 2 \mathrm{H}, \mathrm{H}-4$ and $\mathrm{H}-5), 3.55$ (s, 3H, OMe), $2.44(\mathrm{~s}, 3 \mathrm{H}, \mathrm{CMe})$. Found: $\mathrm{C}, 50.10 ; \mathrm{H}$, $5.75 ; \mathrm{S}, 8.65 \%$. Calcd for $\mathrm{C}_{15} \mathrm{H}_{20} \mathrm{O}_{8} \mathrm{~S}: \mathrm{C}, 49.99 ; \mathrm{H}, 5.59$; $\mathrm{S}, 8.90 \%$.

Methyl 6-Deoxy-2,3-O-methylene- $\alpha$-D-mannopyranoside (11). To a solution of $10(1.0 \mathrm{~g}, 2.8 \mathrm{mmol})$ in dimethyl sulfoxide ( $30 \mathrm{ml}, \mathrm{DMSO})$ was added sodium borohydride $(530 \mathrm{mg}$ ) and the mixture was kept at $80^{\circ} \mathrm{C}$ for $4 \mathrm{~h}$, poured into water $(150 \mathrm{ml})$, and extracted with ether. The etheral extract was treated as usual to give syrupy 11 ( $410 \mathrm{mg}, 77.7 \%$ ) showing a single component on TLC and NMR. $[\alpha]_{\mathrm{D}}$ $+30.8^{\circ}(c 0.9)$; NMR: 5.14 and 4.96 (each s, $2 \mathrm{H}, \mathrm{OCH}_{2} \mathrm{O}$ ), 4.87 (s, $1 \mathrm{H}, \mathrm{H}-1$ ), 4.11 (dd, $1 \mathrm{H}, J_{2,3}=6.0, J_{3,4}=7.0, \mathrm{H}-3$ ), 3.87 (d, $1 \mathrm{H}, \mathrm{H}-2$ ), 3.65 (oct, $1 \mathrm{H}, J_{4,5}=9.2, J_{5,8}=6.0, \mathrm{H}-5$ ), 3.30 (dd, 1H, H-4), 1.29 (d, 3H, H-6), 3.37 (s, 3H, OMe), 2.80 (broad s, $1 \mathrm{H}, \mathrm{OH}$ ). Found: C, $50.47 ; \mathrm{H}, 7.55 \%$.
Calcd for $\mathrm{C}_{8} \mathrm{H}_{14} \mathrm{O}_{5}$ : C, 50.52; H, 7.42\%.

Methyl 6-Deoxy-2,3-O-methylene- $\alpha$-D-lyxo-hexopyranosid-4-ulose (6). To a chilled solution $\left(-78^{\circ} \mathrm{C}\right)$ of DMSO (143 $\mathrm{mg}, 2 \mathrm{mmol})$ in dichloromethane $(2 \mathrm{ml})$ was successively added a solution of trifluoroacetic anhydride $(318 \mathrm{mg}, 1.5$ $\mathrm{mmol})$ in dichloromethane $(2 \mathrm{ml})$ with stirring, and after $10 \mathrm{~min}$, a solution of $11(135 \mathrm{mg}, 0.7 \mathrm{mmol})$ in dichloromethane $(4 \mathrm{ml})$ dropwise. After stirring for $1 \mathrm{~h}$, the reaction mixture was carefully neutralized with triethylamine at $-78^{\circ} \mathrm{C}$, and then poured into ice-water. The resulting solution was extracted with chloroform. The usual workup of the extract gave $6(125 \mathrm{mg}, 93.6 \%)$ as a syrup, showing a single component on TLC and NMR. NMR: 5.17 (s, $1 \mathrm{H}, \mathrm{H}-1$ ), 4.98 and 4.88 (each $\mathrm{s}, 2 \mathrm{H}, \mathrm{OCH}_{2} \mathrm{O}$ ), 4.33 (d, 1H, $J_{2,3}=6.4, \mathrm{H}-2$ ), 4.37 (d, $\left.1 \mathrm{H}, \mathrm{H}-3\right), 4.24$ (q, 1H, $J_{5,6}=$ 7.0, H-5), 3.47 (s, 3H, OMe), 1.37 (d, 3H, H-6).

This syrup was used for the next reaction, without further purification and measurement of the rotational value, because a small amount of impurities detectable in the NMR spectrum could not be removed.

Reaction of 4-Uloses with Methylmagnesium Iodide. Synthesis of 4-C-methyl derivatives is illustrated by the preparation of benzyl 2,3-di-O-benzyl-4- $C$-methyl- $\alpha$-D-xylopyranoside (12) and - $\beta$-L-arabinopyranoside (13). To a chilled solution $\left(-78^{\circ} \mathrm{C}\right)$ of methylmagnesium iodide in ether $(2$ $\mathrm{ml}$ ), prepared from magnesium turnings $(0.12 \mathrm{~g}, 4.9 \mathrm{mmol})$ and methyl iodide $(1 \mathrm{~g}, 7 \mathrm{mmol})$, was added dropwise a solution of $1(0.3 \mathrm{~g}, 0.72 \mathrm{mmol})$ in ether $(1 \mathrm{ml})$, and the mixture was stirred for $2 \mathrm{~h}$ at the same temperature, diluted with ether, and then poured into water. The ether layer was washed with water, dried, and then evaporated to give a syrup. Fractionation of the syrup on a silica-gel column (hexane-ethyl acetate $3: 1$ ) gave $\mathbf{1 2}$ and $\mathbf{1 3}$ as syrups in 27\% $(84 \mathrm{mg})$ and $70.6 \%(220 \mathrm{mg})$ yield, respectively.

When the reaction was carried out in ether-THF (1:1) at room temperature, 12 and 13 were obtained in 60.5 and $24 \%$ yield, respectively. 12: $[\alpha]_{\mathrm{D}}+90.1^{\circ}$ (c 1.1); 13: $[\alpha]_{\mathrm{D}}+102^{\circ}(c$ 5.0). Found for 12: C, 74.23; H, 7.08, and for 13: C, $74.13 ; \mathrm{H}, 7.18 \%$. Calcd for $\mathrm{C}_{27} \mathrm{H}_{30} \mathrm{O}_{5}$ : C, $74.63 ; \mathrm{H}, 6.96 \%$.

A similar reaction of $2(0.2 \mathrm{~g}, 0.8 \mathrm{mmol})$ with methylmagnesium iodide in ether-THF at room temperature and separation of the epimeric products gave benzyl 4-C-methyl2,3-O-methylene- $\alpha$-D-xylopyranoside (18) and $-\beta$-L-arabinopyranoside $(19)$ in $19 \%(40 \mathrm{mg})$ and $53 \%(112 \mathrm{mg})$ yield, respectively. Found for 18: C, $62.86 ; \mathrm{H}, 6.75 \%$, and for 19: C, 63.02; H, 6.63\%. Calcd for $\mathrm{C}_{14} \mathrm{H}_{18} \mathrm{O}_{5}: \mathrm{C}, 63.14$; $\mathrm{H}, 6.81 \%$.

In a similar way, methyl 2,3-di-O-benzyl-6-deoxy-4- $C$ methyl- $\alpha$-D-glucopyranoside (23) and $-\alpha$-D-galactopyranoside (24) were obtained from 7 as syrups in 27 and $59 \%$ yield, respectively. 23: $[\alpha]_{\mathrm{D}}+43.9^{\circ}(c 1.1), 24:[\alpha]_{\mathrm{D}}+81.6^{\circ}(c$ 1.3). Found for 23: C, 70.81; H, 7.35\%, and for 24: C, $70.65 ; \mathrm{H}, 7.47 \%$. Calcd for $\mathrm{C}_{22} \mathrm{H}_{28} \mathrm{O}_{5}: \mathrm{C}, 70.94 ; \mathrm{H}, 7.58 \%$.

The reaction of $\mathbf{5}$ and $\mathbf{6}$ with methylmagnesium iodide as above gave selectively one epimer, methyl 6-deoxy-4-Cmethyl-2,3-O-methylene- $\alpha$-D-allopyranoside $(29)$ and $-\alpha$-Dtalopyranoside $(30)$, respectively. 29: syrup, $[\alpha]_{D}+81.7^{\circ}$ (c 0.8 ), 30: $\mathrm{mp} 105-108^{\circ} \mathrm{C},[\alpha]_{\mathrm{D}}+13.3^{\circ}$ (c 1.3). Found for 29: C, 52.76; $\mathrm{H}, 7.95 \%$, and for 30: C, 52.87; $\mathrm{H}$, $7.99 \%$. Calcd for $\mathrm{C}_{9} \mathrm{H}_{16} \mathrm{O}_{5}: \mathrm{C}, 52.93 ; \mathrm{H}, 7.90 \%$.

Reaction of 4-Uloses with Vinylmagnesium Bromide. Synthesis of 4-C-vinyl derivatives is typically presented by the preparation of benzyl 2,3-di- $O$-benzyl-4- $C$-vinyl- $\alpha$-D-xylopyranoside (14) and $-\beta$-L-arabinopyranoside (15). To a solution of vinylmagnesium bromide, prepared from magnesium turnings $(1.2 \mathrm{~g}, 49 \mathrm{mmol})$ and vinyl bromide $(6 \mathrm{~g}, 56 \mathrm{mmol})$, 
in THF (5 ml) was added with stirring a solution of $\mathbf{1}(3 \mathrm{~g}$, $7.2 \mathrm{mmol})$ in THF $(5 \mathrm{ml})$ at room temperature, and the mixture was stirred for $1 \mathrm{~h}$, poured into a saturated aqueous ammonium chloride solution and then extracted with ether. The usual work-up of the extract and separation of the epimeric products on a silica-gel column (hexane-ethyl acetate $15: 1)$ gave 14 and 15 as syrups in $34.4 \%(1.1 \mathrm{~g})$ and $14 \%$ $(0.45 \mathrm{~g})$ yield, respectively. 14: $[\alpha]_{\mathrm{D}}+109^{\circ}$ (c 0.8$), 15$ : $[\alpha]_{\mathrm{D}}+152^{\circ}$ (c 1.2). Found for 14: C, 75.59; $\mathrm{H}, 6.58 \%$, and for 15: C, $75.31 ; \mathrm{H}, 6.80 \%$. Calcd for $\mathrm{C}_{28} \mathrm{H}_{30} \mathrm{O}_{5}: \mathrm{C}$, $75.31 ; \mathrm{H}, 6.77 \%$.

A similar reaction of $2(1.1 \mathrm{~g}, 4.4 \mathrm{mmol})$ and vinylmagnesium bromide in THF $(10 \mathrm{ml})$, prepared from magnesium turnings $(0.8 \mathrm{~g}, 32.9 \mathrm{mmol})$ and vinyl bromide $(4.0 \mathrm{~g}, 37.3$ $\mathrm{mmol}$ ), and separation of the epimeric products with a preparative TLC (developed four times with hexane-ethyl acetate 4:1) gave benzyl 2,3-O-methylene-4- $C$-vinyl- $\alpha$-Dxylopyranoside $(20)$ and $-\beta$-L-arabinopyranoside $(\mathbf{2 1})$ as syrups in $10.5 \%(129 \mathrm{mg})$ and $47.8 \%(585 \mathrm{mg})$ yield, respectively. 20: $\left.[\alpha]_{\mathrm{D}}+137^{\circ}(c) 3.0\right), 21:[\alpha]_{\mathrm{D}}+170^{\circ}(c$ 1.2). Found for 20: C, $64.87 ; \mathrm{H}, 6.49 \%$, and for 21 : C, 64.24; $\mathrm{H}, 6.48 \%$. Calcd for $\mathrm{C}_{15} \mathrm{H}_{18} \mathrm{O}_{5}: \mathrm{C}, 64.73 ; \mathrm{H}$, $6.52 \%$.

Reaction of 3 (664 $\mathrm{mg}, 1.5 \mathrm{mmol}$ ) as above gave one epimer, benzyl 2,3-di-O-benzyl-6-deoxy-4- $C$-vinyl- $\alpha$-D-galactopyranoside (22) as a syrup in $43.8 \%(310 \mathrm{mg})$ yield. $[\alpha]_{\mathrm{D}}$ $+141^{\circ}$ (c 6.0). Found: C, 74.83; $\mathrm{H}, 6.72 \%$. Calcd for $\mathrm{C}_{29} \mathrm{H}_{32} \mathrm{O}_{5}: \mathrm{C}, 75.63 ; \mathrm{H}, 7.00 \%$.

A similar reaction of $4(4 \mathrm{~g}, 15.1 \mathrm{mmol})$ in THF with vinylmagnesium bromide and separation of the epimeric products with a lobar column (hexane-ethyl acetate 4:1) gave benzyl 6-deoxy-4- $C$-vinyl-2,3- $O$-methylene- $\alpha$-D-glucopyranoside (26) and - $\alpha$-D-galactopyranoside (27) as syrups in $3.4 \%(0.15 \mathrm{~g})$ and $51.8 \%(2.29 \mathrm{~g})$ yield, respectively. 26: $[\alpha]_{\mathrm{D}}+167^{\circ}\left(c\right.$ 2.3). 27: $[\alpha]_{\mathrm{D}}+141^{\circ}$ (c 6.8). Found for 26: C, 64.96; $\mathrm{H}, 6.61 \%$, and for $27: \mathrm{C}, 65.98 ; \mathrm{H}, 6.72 \%$. Calcd for $\mathrm{C}_{16} \mathrm{H}_{20} \mathrm{O}_{5}: \mathrm{C}, 65.74 ; \mathrm{H}, 6.90 \%$.

Reaction of 4-Uloses with 2-Lithio-2-methyl-1,3-dithiane. Synthesis of 4-C-[2-methyl-1,3-dithian-2-yl] derivatives is illustrated by the preparation of benzyl 2,3-di-O-benzyl4-C-(2-methyl-1,3-dithian-2-yl)- $\alpha$-D-xylopyranoside (16) and - $\beta$-L-arabinopyranoside (17). To a chilled solution of 2methyl-1,3-dithiane $(1 \mathrm{~g}, 7.5 \mathrm{mmol})$ in THF $(5 \mathrm{ml})$ was added dropwise butyllithium $(10 \%, 1.3 \mathrm{ml}, 2 \mathrm{mmol})$ in hexane at $-30^{\circ} \mathrm{C}$ (Dry Ice-carbon tetrachloride) under argon atmosphere, and the mixture was stirred for $3 \mathrm{~h}$. A solution of $1(0.3 \mathrm{~g}, 0.72 \mathrm{mmol})$ in THF $(2 \mathrm{ml})$ was further added to the mixture at $-78^{\circ} \mathrm{C}$, and stirred for $1 \mathrm{~h}$. The reaction mixture was poured into water and extracted with ether. The usual work-up of the extract and separation of the eprimeric products on a silica-gel column (benzeneacetone $16: 1$ ) gave $\mathbf{1 6}$ and $\mathbf{1 7}$ as syrups in $25.2 \%(0.1 \mathrm{~g})$ and $10.1 \%(0.04 \mathrm{~g})$ yield, respectively. 16: $[\alpha]_{\mathrm{D}}+82.4^{\circ}$ (c 3.5), NMR: $7.6-7.3(\mathrm{~m}, 15 \mathrm{H}, 3 \times \mathrm{Ph}), 4.76(\mathrm{~d}, 1 \mathrm{H}$, $\left.J_{1,2}=1.3, \mathrm{H}-1\right), 5.05-4.51\left(\mathrm{~m}, 6 \mathrm{H}, 3 \times \mathrm{CH}_{2} \mathrm{Ph}\right.$ ), 4.30 (dd, $\left.1 \mathrm{H}, J_{2,3}=3.0, J_{3,5 \mathrm{a}}=1.0, \mathrm{H}-3\right), 4.30$ and $3.96(\mathrm{ABq}, 2 \mathrm{H}$, $J=11.3 \mathrm{H}-5 \mathrm{e}$ and $\mathrm{H}-5 \mathrm{a}), 3.60$ (dd, $1 \mathrm{H}, \mathrm{H}-2$ ), 3.54-1.70 $\left(\mathrm{m}, 6 \mathrm{H}, \mathrm{SCH}_{2} \mathrm{CH}_{2} \mathrm{CH}_{2} \mathrm{~S}\right), 1.57(\mathrm{~s}, 3 \mathrm{H}, \mathrm{CMe}) . \quad 17:[\alpha]_{\mathrm{D}}$ $+82.4^{\circ}$ (c 3.5); NMR: 7.6-7.3 (m, $\left.15 \mathrm{H}, 3 \times \mathrm{Ph}\right), 5.04$ $4.37\left(\mathrm{~m}, 6 \mathrm{H}, 3 \times \mathrm{CH}_{2} \mathrm{Ph}\right), 4.83$ (d, $\left.1 \mathrm{H}, J_{1,2}=4.0, \mathrm{H}-1\right)$, 4.47 (dd, $1 \mathrm{H}, J_{2,3}=9.2, J_{3,5 \mathrm{e}}=1.0, \mathrm{H}-3$ ), 4.18 and 3.98 (ABq, 2H, $J=12.8, \mathrm{H}-5 \mathrm{e}$ and $\mathrm{H}-5 \mathrm{a}), 3.96$ (dd, $1 \mathrm{H}, \mathrm{H}-3$ ), $3.20-1.50\left(\mathrm{~m}, 6 \mathrm{H}, \mathrm{SCH}_{2} \mathrm{CH}_{2} \mathrm{CH}_{2} \mathrm{~S}\right), 1.96(\mathrm{~s}, 3 \mathrm{H}, \mathrm{CMe})$. Found for 16: C, 67.29; H, 6.34; S, $11.25 \%$, and for 17:
C, 67.41; H, 6.71; S, 11.32\%. Calcd for $\mathrm{C}_{31} \mathrm{H}_{36} \mathrm{O}_{5} \mathrm{~S}_{2}: \mathrm{C}$, $67.36 ; \mathrm{H}, 6.57 ; \mathrm{S}, 11.60 \%$.

In a similar manner, benzyl 6-deoxy-4-C-(2-methyl-1,3dithian-2-yl)-2,3-O-methylene- $\alpha$-D-galactopyranoside (28) was obtained from 4 as a syrup in $35 \%$ yield. $[\alpha]_{\mathrm{D}}+116^{\circ}$ (c 8.0), NMR: 7.6-7.3 (m, Ph), 5.77 and $5.67(\mathrm{ABq}, 2 \mathrm{H}$, $J=12.0, \mathrm{CH}_{2} \mathrm{Ph}$ ), 5.26 (d, $1 \mathrm{H}, J_{1,2}=3.8, \mathrm{H}-1$ ), 5.16 and $5.09\left(\mathrm{ABq}, 2 \mathrm{H}, J=1.0, \mathrm{OCH}_{2} \mathrm{O}\right), 4.29\left(\mathrm{~d}, 1 \mathrm{H}, J_{2.3}=9.7\right.$, $\mathrm{H}-3), 4.28\left(\mathrm{q}, 1 \mathrm{H}, J_{5,6}=6.2, \mathrm{H}-5\right), 3.90(\mathrm{dd}, 1 \mathrm{H}, \mathrm{H}-2), 3.22$ $-1.72\left(\mathrm{~m}, 6 \mathrm{H}, \mathrm{SCH}_{2} \mathrm{CH}_{2} \mathrm{CH}_{2} \mathrm{~S}\right), 2.00(\mathrm{~s}, 3 \mathrm{H}, \mathrm{CMe}), 1.52$ (d, 3H, H-6). Found: C, 57.28; H, 6.58; S, 15.88\%. Calcd for $\mathrm{C}_{19} \mathrm{H}_{26} \mathrm{O}_{5} \mathrm{~S}_{2}$ : C, 57.26; H, 6.58; S, $16.09 \%$.

Reaction of 1 with Methyllithium. To a solution of $\mathbf{1}$ $(0.1 \mathrm{~g}, 0.24 \mathrm{mmol})$ in ether $(10 \mathrm{ml})$, a $1 \mathrm{M}\left(1 \mathrm{M}=1 \mathrm{~mol} \mathrm{dm}^{-3}\right)$ ethereal solution $(1 \mathrm{ml})$ of methyllithium was added with stirring at room temperature. After the reaction mixture was stirred for $1 \mathrm{~h}$, water was added, the ethereal layer was separated, and the aqueous layer was extracted two times with ether $(10 \mathrm{ml})$. The usual work-up of the combined ethereal solution and purification of the product on a preparative TLC (hexane-ethyl acetate 3:1) gave syrupy 12 in $32 \%$ (34 mg) yield.

The present work was supported by a Grant-inAid for Scientific Research No. 347023 from the Ministry of Education, Science and Culture, Japan. The authors wish to thank Mr. Y. Nakamura for the measurements of the ${ }^{13} \mathrm{C}$ NMR spectra.

\section{References}

1) Part XXII. M. Matsuzasa, K. Kubo, H. Kodama, M. Funabashi, and J. Yoshimura, Bull. Chem. Soc. Jpn., 54, 2169 (1981).

2) W. D. Ollis, C. Smith, and D. E. Wright, Tetrahedron, 35, 105 (1979) and literatures cited therein.

3) C. L. Stevens and S. H. Czerreki, Carbohydr. Res., 63, 307 (1978).

4) M. E. Evans and F. W. Parrish, Carbohydr. Res., 54, 105 (1977).

5) J. Yoshimura, K. Sato, and H. Hashimoto, Chem. Lett., 1977, 1327.

6) P. M. Collins and B. R. Whitton, Carbohydr. Res., 33, 25 (1974).

7) a) M. Miljkovic, M. Gligorijevic, T. Satoh, and D. Miljkovic, J. Org. Chem., 39, 1379 (1974); b) M. Miljkovic, M. Gligorijevic, T. Satoh, D. Glisin, and R. D. Pitcher, ibid., 39, 3847 (1974).

8) A. M. Sepulchre, B. Septe, G. Lukacs, and S. D. Gero, Tetrahedron, 30, 905 (1974).

9) P. M. Collins and V. R. N. Munasinghe, Carbohydr. Res., 62, 19 (1978).

10) K. Sato, M. Matsuzawa, K. Ajisaka, and J. Yoshimura, Bull. Chem. Soc. Jpn., 53, 189 (1980).

11) H. Paulsen and V. Sinnwell, Chem. Ber., 111, 879 (1978).

12) M. Matsuzawa and J. Yoshimura, Carbohydr. Res., 81, C5 (1980).

13) J. Yoshimura and M. Matsuzawa, Carbohydr. Res., 85, Cl (1980).

14) J. Yoshimura, Pure Appl. Chem., 53, 113 (1981).

15) C. L. Stevens, R. P. Glinski, and K. G. Taylor, J. Org. Chem., 33, 1586 (1968).

16) B. M. Gough, W. Gunner, W. G. Overend, and N. R. Williams, Carbohydr. Res., 14, 173 (1970). 